\title{
PENGARUH STRUKTUR AKTIVA DAN PROFITABILITAS TERHADAP STRUKTUR MODAL PADA PERUSAHAAN SEKTOR INDUSTRI BARANG KONSUMSI YANG TERDAFTAR DI BURSA EFEK INDONESIA
}

\author{
Anggelita Prichilia Tijow ${ }^{1}$, Harijanto Sabijono ${ }^{2}$, Victorina Z. Tirayoh ${ }^{3}$ \\ 1,2,3 Jurusan Akuntansi, Fakultas Ekonomi dan Bisnis, Universitas Sam Ratulangi, Jl.Kampus Bahu, Manado, \\ 95115, Indonesia \\ E-mail : angelita.prichilia@gmail.com
}

\begin{abstract}
Capital structure discusses the allocation in terms of funding, by looking at the amount of capital from loans with capital derived from the owner of the company. Asset structure may affect the capital structure because firms that have large fixed assets, will tend to get a loan because the asset can be used as collateral. With high profits then the company has adequate internal funds as a source of corporate funding. This study aims to determine the effect of asset structure and profitability on capital structure either partially or simultaneously. The object of this research are 22 companies of consumer goods industry sector listed in Indonesia Stock Exchange. Methods of data analysis using multiple linear regression analysis. The results showed that the asset structure has a positive effect on the capital structure, profitability has a negative effect on capital structure, asset structure and profitability simultaneously affect the capital structure.
\end{abstract}

Keywords: asset structure, profitability, capital structure

\section{PENDAHULUAN}

Setiap perusahaan pasti menginginkan agar usahanya dapat terus dan sukses. Persaingan yang semakin ketat membuat perusahaan berupaya untuk mempertahankan kelangsungan hidup perusahaannya. Perusahaan sebagai suatu entitas yang beroperasi dengan menerapkan prinsip-prinsip ekonomi, umumnya tidak hanya berorientasi pada pencapaian laba maksimal, tetapi juga berusaha meningkatkan nilai perusahaan dan kemakmuran pemiliknya, untuk itu perusahaan memiliki rencana strategis dan taktis yang disusun dalam rangka pencapaian tujuan yang telah ditetapkan (Vitriasari dan Indarti, 2010). Perusahaan membutuhkan modal, modal merupakan salah satu faktor yang dibutuhkan dalam kelangsungan dan menjamin operasi perusahaan selain sumber daya, material maupun faktor pendukung lainnya. Suatu keputusan yang diambil manajer dalam suatu pembelanjaan harus dipertimbangkan secara teliti, sifat dan biaya dari sumber dana yang akan dipilih karena masing-masing sumber dana tersebut memiliki konsekuensi finansial yang berbeda. Karena modal dibutuhkan pada setiap perusahaan apalagi jika perusahaan tersebut akan melakukan ekspansi, maka perusahaan harus menentukan berapa besarnya modal yang dibutuhkan untuk memenuhi atau membiayai usahanya.

Struktur modal dapat diartikan sebagai perimbangan antara penggunaan modal pinjaman yang terdiri dari utang jangka pendek, utang jangka panjang, serta modal sendiri. Struktur modal menggambarkan proporsi hubungan antara utang dan ekuitas, salah satu keputusan penting yang berhubungan dengan maksimisasi return dan berdampak krusial terhadap nilai perusahaan. Struktur modal berbeda antara perusahaan yang satu dengan perusahaan yang lain (Budiarso, 2014). Besarnya struktur modal pada perusahaan tergantung dari banyaknya sumber dana yang diperoleh dari internal perusahaan maupun pihak eksternal perusahaan . 
Struktur aktiva didefinisikan sebagai komposisi aktiva perusahaan yang menunjukkan seberapa besar aktiva perusahaan yang dapat digunakan sebagai jaminan untuk mendapatkan pinjaman. Struktur aktiva dapat mempengaruhi struktur modal karena perusahaan yang memiliki aktiva tetap yang besar, akan cenderung mendapatkan pinjaman dimana aktiva tersebut dapat digunakan sebagai jaminan untuk meningkatkan aktivitas operasinya. Profitabilitas menggambarkan seberapa besar kemampuan perusahaan dalam menghasilkan laba. Dengan laba yang tinggi, maka akan membuat banyak investor menanamkan sahamnya di perusahaan tersebut. Selain itu, dengan laba yang tinggi maka perusahaan memiliki dana internal yang memadai sebagai sumber pendanaan perusahan.

Menurut Riyanto dalam Restiyowati (2014) ada beberapa faktor yang dapat mempengaruhi struktur modal diantaranya adalah : stabilitas penjualan, struktur aktiva, leverage operasi, tingkat pertumbuhan (growth), profitabilitas, pajak, pengawasan, sifat manajemen, sikap kreditur dan konsultan, ukuran perusahaan (firm size), risiko, kondisi pasar, kondisi internal perusahaan dan fleksibilitas keuangan. Faktor-faktor tersebut akan menjadi dasar pertimbangan keputusan manajer. Penelitian ini dilakukan karena struktur modal merupakan salah satu faktor tingkat kepercayaan bagi para investor sebelum membeli saham. Dengan struktur modal yang optimal, maka semakin banyak investor menanamkan investasinya.

Indonesia merupakan negeri yang kaya akan sumber daya alam sehingga banyak komoditi yang dapat diproduksi. Hal ini juga didukung dengan sumber daya manusia yang jumlahnnya cukup besar dan menyebabkan di Indonesia banyak perusahaan yang berkembang disektor industri barang konsumsi (Waruwu, 2011). Sektor industri barang konsumsi terdiri dari sub sektor makanan dan minuman, sub sektor rokok, sub sektor farmasi, sub sektor kosmetik dan barang keperluan rumah tangga, sub sektor peralatan rumah tangga, dan sub sektor lainnya. Tujuan dalam penelitian ini adalah untuk :

1. Untuk mengetahui pengaruh struktur aktiva terhadap struktur modal perusahaan sektor industri barang konsumsi yang terdaftar di Bursa Efek Indonesia.

2. Untuk mengetahui pengaruh profitabilitas terhadap struktur modal perusahaan sektor industri barang konsumsi yang terdaftar di Bursa Efek Indonesia.

3. Untuk mengetahui pengaruh struktur aktiva dan profitabilitas terhadap struktur modal perusahaan sektor industri barang konsumsi yang terdaftar di Bursa Efek Indonesia.

\section{TINJAUAN PUSTAKA}

\subsection{Struktur Modal}

Struktur modal merupakan perimbangan atau perbandingan antara modal asing dan modal sendiri. Modal asing yang dimaksudkan dalam hal ini adalah utang baik jangka panjang maupun jangka pendek. Sedangkan modal sendiri dapat terdiri atas laba ditahan dan juga dengan penyertaan kepemilikan perusahaan (Febriminanto, 2012). Menurut Riyanto dalam Kurniawan (2015) struktur modal menunjukkan proposi atas penggunaan hutang dan ekuitas untuk membiayai aktivitas perusahaan. Semakin ketatnya persaingan bisnis saat ini, sumber pendanaan yang berasal modal sendiri seringkali dirasa kurang. Hal tersebut mendorong manajer keuangan untuk melakukan alternatif pendanaan selain dari modal sendiri yaitu dengan cara menggalang dana dari luar perusahaan berupa utang. Struktur modal memiliki beberapa teori yaitu:

\section{a. Pecking Order Theory}

Dasar pemikiran dari pecking order theory adalah adanya asimetri informasi dan kecenderungan perusahaan untuk mengutamakan penggunaan dana internal dibandingkan dana eksternal. Menurut Myers dalam Kurniawan (2015) hal yang paling penting dari pecking order theory adalah : 
Perusahaan lebih mengutamakan pendanaan internal, karena pendanaan internal merupakan sumber pendanaan dengan resiko yang paling rendah

a. Perusahaan dapat menyesuaikan target pembayaran dividen terhadap peluang investasi.

b. Keputusan deviden yang bersifat sticky, ditambah dengan ketidakstabilan dalam profitabilitas, yang berarti cash flow perusahaan bisa lebih besar atau lebih kecil dari pengeluaran investasinya. Jika cash flow perusahan lebih kecil daripada pengeluaran investasi maka perusahaan dapat menerbitkan sekuritas.

c. Jika perusahaan membutuhkan dana, perusahaan akan memulai dari sekuritas yang paling aman terlebih dahulu yaitu hutang, kemudian hybrid securities seperti convirtable bonds, baru kemudian menerbitkan saham.

b. Trade Off Theory

Teori ini menyatakan bahwa rasio hutang yang optimal ditentukan berdasarkan pada perbandingan antara manfaat dan biaya yang timbul akibat penggunaan hutang. Menurut (Prasetyo, 2015) tambahan hutang masih dapat ditoleransi oleh perusahaan selama manfaat yang diberikan dari penggunaan utang masih lebih besar daripada biaya yang timbul akibat utang itu sendiri, selain itu tambahan utang masih dapat dilakukan selama masih adanya aktiva tetap sebagai jaminan, namun jika biaya hutang sudah terlalu tinggi, perusahaan sebaiknya tidak menambah hutang lagi agar terhindar dari resiko yang tidak diinginkan.. Struktur modal dalam penelitian ini diproksikan dengan Debt to Equity Ratio (DER).

$$
\text { DER }=\frac{\text { Total Debt }}{\text { Total Equity }} \times 100 \%
$$

\subsection{Struktur Aktiva}

Struktur aktiva merupakan perbandingan antara aktiva tetap dengan total aktiva yang dimiliki perusahaan. Menurut Devi, Sulindawati, dan Wahyuni (2017) perusahaan dengan struktur aktiva yang tinggi cenderung memilih menggunakan dana dari pihak luar atau hutang untuk mendanai kebutuhan modalnya. Mai dalam Prasetyo (2015) menyatakan struktur aset merupakan salah salah satu faktor penting pada capital structure perusahaan, karena apabila perusahaan dihadapkan pada kondisi kesulitan keuangan dalam membayar hutangnya, asetaset berwujud atau aset tetap yang dimiliki perusahaan dapat bertindak sebagai jaminan kepada pihak luar yang memberikan pinjamanVariabel ini diproksikan dengan FAR (fixed assets ratio). Tujuan dari penghitungan rasio ini adalah untuk mengetahui seberapa besar porsi aktiva tetap yang dapat dijadikan perusahaan sebagai jaminan atas pinjaman yang dilakukannya dan diukur dengan satuan \%. Menurut Devi dkk (2017) FAR dirumuskan sebagai berikut :

$$
\text { FAR }=\frac{\text { Total Aktiva Tetap }}{\text { Total Aktiva }} \times 100 \%
$$

\subsection{Profitabilitas}

Profitabilitas adalah kemampuan perusahaan untuk menghasilkan laba. Semua perusahaan tentu memiliki tujuan utama yaitu untuk memperoleh keuntungan (profit). Dengan keuntungan tersebut perusahaan dapat menjalankan berbagai aktivitasnya dan menjaga keberlangsungan perusahaan dimasa yang akan datang. Profitabilitas merupakan salah satu faktor yang mempengaruhi struktur modal melalui kemampuan perusahaan dalam menghasilkan laba dari berbagai aktivitas perusahaan dengan kebijakan dan keputusan yang dilakukan perusahaan dalam periode tertentu. Dalam penelitian ini profitabilitas diproksikan dengan ROA (Return On Asset). Rasio ini mengukur kemampuan perusahaan menghasilkan 
laba bersih berdasarkan tingkat aset yang tertentu dan diukur dengan satuan \%. Menurut Udayani dan Suaryana (2013) ROA dapat dihitung dengan:

$$
\text { ROA }=\frac{\text { Laba Bersih setelah Pajak }}{\text { Total Aktiva }} \times 100 \%
$$

\subsection{Pengaruh Struktur Aktiva Terhadap Struktur Modal}

Struktur aktiva dalam penelitian ini adalah perbandingan aktiva tetap dan total aktiva perusahaan yang menggambarkan besarnya aktiva yang dapat dijaminkan perusahaan ketika melakukan pinjaman kepada pihak kreditur. Berdasarkan pada Trade-off theory, struktur aktiva berpengaruh positif terhadap struktur modal. Semakin banyak aset suatu perusahaan berarti semakin banyak collateral assets untuk bisa mendapat sumber dana eksternal berupa hutang (Sansoethan dan Suryono, 2016). Semakin besar struktur aktiva, maka struktur modal perusahaan yang berasal dari hutang akan semakin meningkat. Banyak penelitian yang telah melakukan penelitian tentang struktur aktiva terhadap struktur modal seperti penelitian Akinyomi dan Olagunju (2013), Ichwan (2015), yang menunjukan bahwa struktur aktiva berpengaruh posititif terhadap struktur modal. Berdasarkan penjelasan tersebut maka dibuat hipotesis sebagai berikut :

H1 : Struktur Aktiva berpengaruh positif terhadap struktur modal.

\subsection{Pengaruh Profitabilitas Terhadap Struktur Modal}

Pecking Order theory menyatakan bahwa perusahaan lebih mengutamakan pendanaan internal. Perusahaan dengan profitabilitas tinggi memiliki dana internal yang memadai sehingga perusahaan akan menggunakan dana internal terlebih dahulu. Semakin tinggi profit yang dihasilkan perusahaan, maka akan semakin mengurangi struktur modal perusahaan yang berasal dari hutang. Perusahaan dengan tingkat keuntungan yang tinggi, umumnya menggunakan hutang yang relatif sedikit karena dengan keuntungan yang tinggi tersebut dapat digunakan sebagai sumber dana. Hal ini sejalan dengan penelitian yang dilakukan oleh Udayani dan Suaryana (2013), Handojo (2015), Nanda dan Retnani (2017), Yushinta dan Suryandari (2010), yang menyatakan bahwa profitabilitas berpengaruh negatif terhadap struktur modal. Berdasarkan penjelasan tersebut maka diuraikan hipotesis sebagai berikut :

H2 : Profitabilitas berpengaruh negatif terhadap struktur modal.

\subsection{Pengaruh Struktur Aktiva dan Profitabilitas Terhadap Struktur Modal}

Struktur modal menunjukkan proporsi atas penggunaan hutang dan modal sendiri untuk membiayai aktivitas perusahaan. Struktur aktiva menggambarkan besarnya aktiva yang dapat dijaminkan kepada pihak kreditur ketika perusahaan membutuhkan dana dari pihak eksternal. Berdasarkan Trade Off Theory dalam penelitian Prasetyo (2015) yang menyatakan bahwa tambahan utang masih dilakukan selama masih adanya aktiva tetap sebagai jaminan. Maka perusahaan dengan struktur aktiva yang besar cenderung untuk menghimpun dana dari pihak eksternal pun akan semakin tinggi. Sehingga akan meningkatkan struktur modal perusahaan yang berasal dari hutang. Tetapi jika biaya yang ditimbulkan dari hutang sudah terlalu tinggi, perusahaan seharusnya tidak menambah hutang lagi untuk menghindari resiko yang tidak diinginkan. Profitabilitas adalah kemampuan perusahaan dalam menghasilkan laba. Menurut Pecking Order theory perusahaan akan mengutamakan sumber pendanaan dari internal perusahaan, sehingga ketika perusahaan mendapatkan laba yang besar maka pembiayaan dari pihak eksternal akan berkurang.

H3 : Struktur Aktiva dan Profitabilitas berpengaruh terhadap struktur modal. 


\section{METODE PENELITIAN}

\subsection{Jenis Penelitian}

Jenis penelitian dalam penelitian ini adalah penelitian kuantitatif, ditinjau dari tingkat eksplanasi penelitian ini merupakan penelitian asosiatif. Penelitian asosiatif merupakan penelitian yang bertujuan untuk mengetahui hubungan dua variabel atau lebih (Sugiyono, 2016:21).

\subsection{Tempat dan Waktu Penelitian}

Penelitian ini mengambil data melalui situs resmi Bursa Efek Indonesia di www.idx.co.id dan di pusat informasi pasar modal yang terletak di J1. Piere Tendean Komp.Mega Mas Boulevard, Manado. Penelitian ini dilaksanakan pada bulan April 2018 sampai dengan Mei 2018.

\subsection{Populasi dan Sampel}

Populasi pada penelitian ini adalah seluruh perusahaan sektor industri barang konsumsi yang terdaftar di Bursa Efek Indonesia selama tahun 2014-2016. Jumlah populasi yang dijadikan objek penelitian adalah sebanyak 39 perusahaan. Sampel yang digunakan dalam penelitian ini adalah perusahaan-perusahaan sektor industri barang konsumsi yang terdaftar di Bursa Efek Indonesia (BEI) tahun 2014-2016 dan memenuhi kriteria yang disyaratkan dalam penelitian. Berdasarkan purposive sampling terdapat 22 perusahaan yang memenuhi kriteria untuk dijadikan sampel penelitian. Unit analisis yang digunakan adalah tahun perusahaan sektor industri barang konsumsi yang terdaftar di BEI selama waktu penelitian yaitu 20142016.

\subsection{Metode Sampling}

Metode pemilihan sampel penelitian ini menggunakan purposive sampling. Kriteria yang akan digunakan untuk memilih sampel dalam penelitian ini adalah sebagai berikut:

1. Perusahaan sektor industri barang konsumsi yang terdaftar di Bursa Efek Indonesia sebelum tahun 2014 sampai dengan tahun 2016.

2. Perusahaan sektor industri barang konsumsi yang mempublikasikan laporan keuangan per 31 Desember secara lengkap dan berturut turut dari tahun 2014-2016.

3. Perusahaan sektor industri barang konsumsi yang mendapatkan laba berturut-turut selama tahun 2014-2016.

\subsection{Metode Analisis}

Metode analisis yang digunakan adalah analisis regresi linear berganda dan diawali dengan uji asumsi klasik yang terdiri dari uji normalitas, uji multikolinearitas, uji heteroskedastisitas, dan uji autokorelasi sebagai prasyarat untuk melakukan pengujian hipotesis.

\section{HASIL ANALISIS DAN PEMBAHASAN}

\subsection{Hasil Analisis}

\subsubsection{Uji Outlier}

Deteksi adanya outlier univariate dapat dilakukan dengan menentukan nilai ambang batas yang dikategorikan sebagai outlier dengan cara mengkonversikan nilai data penelitian kedalam standart score atau disebut juga dengan Z-score yang mempunyai nilai rata-rata nol dan standart deviasi satu. Observasi data yang memiliki Z-score $\pm 2,5$ akan dikategorikan sebagai outlier. Hasil uji outlier pada Struktur Aktiva (X1), Profitabilitas (X2) dan Struktur Modal (Y) adalah: 


\section{Tabel 4.1 Hasil Uji Outlier \\ Descriptive Statistic}

\begin{tabular}{|l|l|l|r|r|l|}
\hline & N & Minimum & Maximum & Mean & $\begin{array}{l}\text { Std. } \\
\text { Deviation }\end{array}$ \\
\hline Zscore: Struktur Aktiva & 66 & $-1,63535$ & 2,89437 & 0,0000000 & 1,00000000 \\
\hline Zscore: Profitabilitas & 66 & $-1,20296$ & 3,46130 & 0,0000000 & 1,00000000 \\
\hline Zscore: Struktur Modal & 66 & $-1,13258$ & 4,34707 & 0,0000000 & 1,00000000 \\
\hline Valid N (listwise) & 66 & & & & \\
\hline
\end{tabular}

(Sumber : Hasil Pengolahan Data Aplikasi SPSS, 2018)

Berdasarkan hasil descriptive statistics pada tabel diatas menunjukkan bahwa pada variabel penelitian yaitu struktur aktiva (FAR), profitabilitas (ROA) dan struktur modal (DER), terdapat outlier karena nilai $z$-score yang dihasilkan diluar selang $\pm 2,5$. Dengan demikian, jumlah data outlier yaitu sebanyak 4 (empat) data sehingga jumlah observasi untuk uji selanjutnya sebanyak $66-4=62$ (enam puluh dua) data atau observasi.

\subsubsection{Uji Asumsi Klasik}

Uji asumsi klasik adalah uji prasyarat yang harus dilakukan terlebih dahulu sebelum melakukan analisis data. Uji asumsi klasik diterapkan guna memperoleh hasil estimasi yang valid secara ekonometri, dalam arti bahwa analisis yang akan diterapkan tidak menyimpang dari teori ekonomi. Adapun, uji asumsi klasik yang diterapkan dalam penelitian ini meliputi uji normalitas, uji multikolinieritas, dan uji heteroskedastisitas dan uji autokorelasi.

\section{Uji Normalitas}

Uji normalitas dilakukan dengan melihat nilai Asymp. Sig (2-Tailed) menggunakan uji statistik non-parametrik Kolmogorov-Smirnov $(K-S)$. Uji normalitas bertujuan untuk menguji apakah data variabel independen dan dependen berdistribusi normal atau tidak. Sehingga apabila data telah berdistribusi normal maka bisa dilanjutkan ke tahap berikutnya. Berikut ini adalah hasil uji normalitas.

Tabel 4.2 Hasil Uji Normalitas

\begin{tabular}{|l|l|r|}
\hline \multicolumn{1}{|c|}{ Unstandardized Residual } & & 62 \\
\hline $\mathrm{N}$ & & 0,0000000 \\
\hline Normal Parameters ${ }^{\mathrm{a}, \mathrm{b}}$ & Mean & 34,26823614 \\
\hline & Std. Deviation & 0,103 \\
\hline Most Extreme Differences & Absolute & 0,103 \\
\hline & Positive & $-0,051$ \\
\hline & Negative & 0,103 \\
\hline Test Statistic & & $0,099^{\mathrm{c}}$ \\
\hline Asymp. Sig. (2-tailed) & & \\
\hline
\end{tabular}

(Sumber : Hasil Pengolahan Data Aplikasi SPSS, 2018)

Dari tampilan output SPSS di atas menunjukkan bahwa angka signifikansi atau Asymp. Sig. (2-tailed) yang diperoleh sebesar 0,099 dimana nilai ini melebihi 0,05 (dalam kasus ini menggunakan taraf signifikansi sebesar 5\% atau $\alpha=5 \%$ ) sehingga residual mengikuti distribusi normal. Variabel struktur aktiva (FAR), profitabilitas (ROA) dan struktur modal (DER) berdistribusi normal, dengan begitu berarti penelitian dapat dilakukan pada tahap selanjutnya. 


\section{Uji Multikolinearitas}

Uji multikolinearitas bertujuan untuk menguji apakah model regresi ditemukan adanya korelasi antar variabel bebas (independen). Uji multikonolieritas dalam penelitian ini dilakukan dengan melihat nilai tolerance dan variance inflation factor (VIF). Kedua ukuran ini menunjukkan setiap variabel independen manakah yang menjelaskan oleh variabel independen lainnya Nilai cut-off yang umum dipakai untuk menunjukkan terjadi multikolinearitas adalah nilai tolerance $<0,1$ dan nilai VIF>10 (Prasetyo 2015).

\section{Tabel 4.2 Hasil Uji Multikolinearitas}

\section{Coefficients ${ }^{\mathrm{a}}$}

\begin{tabular}{|l|r|r|}
\hline \multirow{2}{*}{ Model } & \multicolumn{2}{|c|}{ Collinearity Statistics } \\
\cline { 2 - 3 } 1 (Constant) & Tolerance & VIF \\
\hline Struktur Aktiva & 0,834 & 1,199 \\
\hline Profitabilitas & 0,834 & 1,199 \\
\hline
\end{tabular}

(Sumber : Hasil Pengolahan Data Aplikasi SPSS, 2018)

Berdasarkan tabel 4.2 nilai tolerance tidak ada yang bernilai dibawah 0,1 dan nilai Variance Inflation Factor (VIF) menunjukkan nilai yang sama yaitu tidak ada satu variabel yang memiliki nilai VIF lebih besar dari 10 . Hal ini dapat dilihat dari nilai Tolerance struktur aktiva dan profitabilitas sebesar 0,834 dan Variance Inflation Factor pada variabel struktur aktiva dan profitabilitas sebesar 1,199. Maka dapat disimpulkan bahwa model regresi dalam penelitian ini tidak terjadi multikolinieritas dan model regresi layak digunakan.

\section{Uji Heteroskedastisitas}

Uji ini dapat dapat diidentifikasikan dengan cara menghitung koefisien korelasi Rank Spearman antara nilai residual dengan seluruh variabel bebas. Hasil dari uji Rank Spearman adalah sebagai berikut :

Tabel 4.3 Hasil Uji Heteroskedastisitas Correlations

\begin{tabular}{|c|l|c|}
\hline Variabel & Sig. & Rank Spearman \\
\hline Struktur Aktiva & 0,563 & $-0,075$ \\
\hline Profitabilitas & 0,482 & $-0,091$ \\
\hline
\end{tabular}

(Sumber : Hasil Pengolahan Data Aplikasi SPSS, 2018)

Berdasarkan tabel 4.3 dapat disimpulkan bahwa model regresi linier berganda yang dihasilkan tidak terjadi heteroskedastisitas, karena tingkat signifikansi pada variabel struktur aktiva dan profitabilitas yaitu 0,563 dan 0,482 dimana nilai signifikansi keduanya lebih besar dari 0,05 atau $5 \%$.

\section{Uji Autokorelasi}

Untuk mendeteksi keberadaan autokorelasi akan digunakan pengujian Durbin-Watson. Berikut adalah hasil pengujian Durbin Watson: 
Tabel 4.4 Hasil Uji Autokorelasi

Model Summary ${ }^{\mathrm{b}}$

\begin{tabular}{|c|c|c|c|c|c|}
\hline Model & $\mathrm{R}$ & $\begin{array}{c}\mathrm{R} \\
\text { Square }\end{array}$ & $\begin{array}{l}\text { Adjusted R } \\
\text { Square }\end{array}$ & $\begin{array}{l}\text { Std. Error of the } \\
\text { Estimate }\end{array}$ & $\begin{array}{l}\text { Durbin- } \\
\text { Watson }\end{array}$ \\
\hline 1 & $0,583^{\mathrm{a}}$ & 0,339 & 0,317 & 34,84421 & 1,810 \\
\hline
\end{tabular}

(Sumber : Hasil Pengolahan Data Aplikasi SPSS, 2018)

Berdasarkan tabel DW, nilai dL untuk $\mathrm{n}=62$ dan $\mathrm{k}=2$ yaitu sebesar 1,5232 dan nilai $\mathrm{dU}$ yaitu sebesar 1,6561. Nilai Durbin Watson pada tabel diatas menunjukkan angka 1,810. Sehingga dU $<\mathrm{d}<4$-dU, yaitu 1,6561 $<1,810<2,3439$. Berdasarkan kriteria tabel nilai uji Durbin Watson hasil ini menunjukan tidak ada autokorelasi positif atau negatif artinya bahwa model regresi penelitian ini bebas dari autokorelasi.

\subsubsection{Analisis Regresi Linier Berganda}

\section{Tabel 4.5 Hasil Analisis Regresi} Coefficients $^{\mathrm{a}}$

\begin{tabular}{|c|c|c|c|c|c|c|}
\hline \multirow{2}{*}{\multicolumn{2}{|c|}{ Model }} & \multicolumn{2}{|c|}{$\begin{array}{c}\text { Unstandardized } \\
\text { Coefficients }\end{array}$} & \multirow{2}{*}{$\begin{array}{c}\text { Standardized } \\
\text { Coefficients } \\
\text { Beta }\end{array}$} & \multirow[b]{2}{*}{$\mathrm{t}$} & \multirow[b]{2}{*}{ Sig. } \\
\hline & & B & $\begin{array}{l}\text { Std. } \\
\text { Error }\end{array}$ & & & \\
\hline \multirow[t]{3}{*}{1} & (Constant) & 62,920 & 16,469 & & 3,820 & 0,000 \\
\hline & Struktur Aktiva & 0,987 & 0,345 & 0,332 & 2,862 & 0,006 \\
\hline & Profitabilitas & $-2,172$ & 0,694 & $-0,362$ & $-3,128$ & 0,003 \\
\hline
\end{tabular}

(Sumber : Hasil Pengolahan Data Aplikasi SPSS, 2018)

Berdasarkan hasil dari tabel di atas dapat dikembangkan dengan menggunakan model persamaan regresi linier berganda sebagai berikut:

$$
\mathrm{Y}=69,920+0,987 \mathrm{X} 1-2,172 \mathrm{X} 2+\mathrm{e}
$$

Keterangan:

Y : Struktur Modal

$\mathrm{X} 1$ : Struktur Aktiva

$\mathrm{X} 2$ : Profitabilitas

e : Standart error

Hasil persamaan regresi ini secara keseluruhan menunjukkan hasil interpretasi sebagai berikut:

a. Konstanta $(\alpha)$ sebesar 69,920 artinya jika tidak terdapat nilai struktur aktiva (X1) dan profitabilitas (X2) atau sama dengan nol maka struktur modal nilainya sebesar 69,920\%.

b. Koefisien regresi X1 $\left(\beta_{1}\right)$ yang merupakan variabel struktur aktiva sebesar 0,987 artinya setiap kenaikan satu satuan variabel struktur aktiva akan meningkatkan struktur modal sebesar $0,987 \%$. Begitu pula sebaliknya, setiap penurunan satu satuan struktur aktiva akan menurunkan nilai struktur modal sebesar 0,987\% dengan anggapan bahwa profitabilitas tetap. Koefisien bernilai positif menunjukkan arah hubungan yang searah antara variabel struktur aktiva dengan struktur modal. Semakin tinggi struktur aktiva, maka struktur modal akan semakin meningkat.

c. Koefisien regresi X2 $\left(\beta_{2}\right)$ yang merupakan variabel profitabilitas sebesar -2,172 artinya setiap kenaikan satu satuan profitabilitas akan menurunkan nilai struktur modal sebesar $2,172 \%$. Begitu pula sebaliknya, setiap penurunan satu satuan profitabilitas, akan 
meningkatkan struktur modal sebesar 2,172\% dengan anggapan bahwa struktur modal tetap. Koefisien bernilai negatif menunjukkan arah hubungan yang berlawanan antara variabel profitabilitas dengan struktur modal. Semakin tinggi profitabilitas, maka struktur modal akan semakin rendah.

\subsubsection{Koefisien Determinasi $\left(\mathbf{R}^{2)}\right.$}

Koefisien determinasi pada regresi linear dimaksudkan untuk mengetahui seberapa besar kemampuan semua variabel bebas dalam menjelaskan varians dari variabel terikatnya.

Tabel 4.6 Koefisien Determinasi Model Summary ${ }^{\mathrm{b}}$

\begin{tabular}{|c|c|c|}
\hline Model & R & R Square \\
\hline 1 & $0,583^{\mathrm{a}}$ & 0,339 \\
\hline
\end{tabular}

(Sumber : Hasil Pengolahan Data Aplikasi SPSS, 2018)

Dapat dilihat bahwa angka koefisien determinasi $\left(\mathrm{R}^{2}\right)$ sebesar 0,339 Hal ini berarti kemampuan variabel struktur aktiva dan profitabilitas dalam menerangkan variasi perubahan variabel struktur modal sebesar 33,9\% sedangkan sisanya sebesar 66,1\% (100-33,9\%) diterangkan oleh faktor-faktor lain di luar model regresi yang dianalisis.

\subsubsection{Uji Hipotesis}

a. Uji Parsial (uji t)

Uji ini untuk mengetahui seberapa besar pengaruh struktur aktiva dan profitabilitas perusahaan terhadap strukur modal sebagai variabel dependen. Dasar keputusan yang diambil adalah dengan melihat tingkat signifikansi kurang dari 0,05 (5\%).

Tabel 4.7 Uji t (Uji Parsial)

Coefficients $^{\mathrm{a}}$

\begin{tabular}{|c|c|c|c|c|c|c|}
\hline \multirow{2}{*}{ Model } & \multicolumn{2}{|c|}{$\begin{array}{c}\text { Unstandardized } \\
\text { Coefficients }\end{array}$} & $\begin{array}{c}\text { Standardized } \\
\text { Coefficients }\end{array}$ & \multirow{2}{*}{$\mathrm{T}$} & \multirow{2}{*}{ Sig. } \\
\cline { 3 - 7 } \multicolumn{2}{|c|}{} & B & Std. Error & Beta & & \\
\hline \multirow{3}{*}{1} & (Constant) & 62,920 & 16,469 & & 3,820 & 0,000 \\
\cline { 2 - 7 } & $\begin{array}{c}\text { Struktur } \\
\text { Aktiva }\end{array}$ & 0,987 & 0,345 & 0,332 & 2,862 & 0,006 \\
\cline { 2 - 7 } & Profitabilitas & $-2,172$ & 0,694 & $-0,362$ & $-3,128$ & 0,003 \\
\hline
\end{tabular}

(Sumber : Hasil Pengolahan Data Aplikasi SPSS, 2018)

Berdasarkan tabel 4.11, hasil uji t dapat disimpulkan bahwa pada variabel struktur aktiva diperoleh $\mathrm{t}$ hitung sebesar 2,862 dengan signifikasi sebesar 0,006 yang nilainya dibawah 0,05. Dengan demikian H1 diterima, yang artinya secara parsial terdapat pengaruh positif antara variabel X1 struktur aktiva dan variabel Y struktur modal. Sedangkan variabel profitabilitas diperoleh $\mathrm{t}$ hitung sebesar $-3,128$ dengan signifikansi sebesar 0,003 yang nilainya dibawah 0,05 . Dengan demikian $\mathrm{H} 2$ diterima, yang artinya secara parsial terdapat pengaruh negatif antara variabel X2 profitabilitas dan variabel Y struktur modal. 


\section{b. Uji Simultan (Uji F)}

Tabel 4.7 Hasil Uji F (Uji Simultan) ANOVA $^{\mathrm{a}}$

\begin{tabular}{|l|r|r|r|r|r|}
\hline Model & $\begin{array}{l}\text { Sum of } \\
\text { Squares }\end{array}$ & Df & Mean Square & F & Sig. \\
\hline Regression & 36793,446 & 2 & 18396,723 & 15,152 & $0,000^{\mathrm{b}}$ \\
\hline Residual & 71633,033 & 59 & 1214,119 & & \\
\hline Total & 108426,478 & 61 & & & \\
\hline
\end{tabular}

(Sumber : Hasil Pengolahan Data Aplikasi SPSS, 2018)

\subsection{Pembahasan}

\subsubsection{Pengaruh Struktur Aktiva dan Profitabilitas Terhadap Struktur Modal}

Hasil penelitian menunjukkan hipotesis pertama diterima, yaitu struktur aktiva berpengaruh positif terhadap struktur modal. Hal ini menandakan bahwa semakin besar struktur aktiva perusahaan, maka stuktur modal perusahaan yang berasal dari hutang akan semakin meningkat. Pengaruh positif tersebut sesuai dengan Trade Off Theory yang menyatakan bahwa tambahan hutang masih dilakukan selama masih adanya aset tetap sebagai jaminan. Hal ini sejalan dengan penelitian, Ichwan (2015), Zahroh dan Fitria (2016), dan Ferawati dalam Agustini (2015) yang menyatakan struktur aktiva berpengaruh positif terhadap struktur modal. Aktiva berwujud yang semakin besar akan menunjukkan kemampuan perusahaan dalam memberikan jaminan yang lebih tinggi, sehingga dengan mengasumsikan semua faktor lain konstan, perusahaan akan meningkatkan hutang untuk mendapatkan keuntungan dari penggunaan hutang. Serta sejalan dengan penelitian Putra dan Diantini (2015) yang menyatakan struktur aktiva berpengaruh positif terhadap struktur modal, dikarenakan perusahaan dengan struktur aktiva yang tinggi dapat memanfaatkan aset tetapnya sebagai jaminan untuk memperoleh akses berutang yang lebih baik.

\subsubsection{Pengaruh Profitabilitas Terhadap Struktur Modal}

Hasil penelitian menunjukkan hipotesis kedua dalam penelitian ini diterima, yaitu profitabilitas berpengaruh negatif terhadap struktur modal. Hal ini menandakan bahwa semakin besar tingkat profitabilitas yang diperoleh perusahaan, maka struktur modal perusahaan yang berasal dari hutang akan semakin menurun. Pengaruh negatif tersebut sesuai dengan pecking order theory yang menyatakan bahwa perusahaan lebih cenderung mengutamakan penggunaan modal sendiri sebagai sumber pendanaan internal. Perusahaan dengan profitabilitas yang tinggi memiliki dana internal yang memadai sehingga perusahaan akan menggunakan dana internal terlebih dahulu. Hal ini sejalan dengan penelitian yang dilakukan oleh Udayani dan Suaryana (2013) dan Nita dan Hairul (2017), yang menyatakan bahwa tingkat pengembalian yang tinggi juga memungkinkan untuk membiayai sebagian besar kebutuhan pendanaan yang dihasilkan secara internal.

\subsubsection{Pengaruh Struktur Aktiva dan Profitabilitas Terhadap Struktur Modal}

Hasil pengujian secara simultan menunjukkan $\mathrm{F}$ hitung sebesar 15,103 dengan signifikansi $0,000<0,05$. Hasil memperlihatkan bahwa struktur aktiva dan profitabilitas secara bersama-sama berpengaruh terhadap struktur modal. Maka dari itu hipotesis ketiga dalam penelitian ini diterima.

\section{KESIMPULAN DAN SARAN}

\subsection{Kesimpulan}

Berdasarkan data penelitian yang diolah dengan metode regresi linier berganda, kesimpulan yang diambil adalah:: 
1. Struktur aktiva berpengaruh positif terhadap struktur modal perusahaan sektor industri barang konsumsi yang terdaftar di Bursa Efek Indonesia. Dengan demikian hipotesis pertama ( $\mathrm{H} 1)$ diterima Motivasi karir $\left(\mathrm{X}_{2}\right)$ berpengaruh signifikan terhadap minat mahasiswa akuntansi mengikuti pendidikan profesi akuntansi (PPAk). Hal ini dapat disebabkan karena didorong oleh keinginan mahasiswa untuk menjadi profesional di bidang akuntansi.

2. Profitabilitas berpengaruh negatif terhadap struktur modal perusahaan sektor industri barang konsumsi yang terdaftar di Bursa Efek Indonesia. Dengan demikian hipotesis kedua (H2) diterima.

3. Struktur aktiva dan profitabilitas secara bersama-sama berpengaruh terhadap struktur modal perusahaan sektor industri barang konsumsi yang terdaftar di Bursa Efek Indonesia. Dengan demikian hipotesis ketiga (H3) diterima

\subsection{Saran}

Berdasarkan hasil penelitian tentang pengaruh struktur aktiva dan profitabilitas terhadap struktur modal pada perusahaan sektor industri barang konsumsi yang terdaftar di Bursa Efek Indonesia dan terkait dengan keterbatasan penelitian ini, maka penulis memberikan saran yang diharapkan dapat bermanfaat bagi pihak-pihak yang berkepentingan. Adapun saran tersebut adalah:

1. Bagi Perusahaan, agar perusahaan dapat memanfaatkan profit yang didapatkan sebelum melakukan peminjaman dana dari pihak eksternal. Perusahaan hendaknya dapat menentukan sumber-sumber pendanaan yang optimal yang dapat membentuk struktur modal dengan baik. Sehingga perusahaan-perusahaan dapat terus bersaing dan terhindar dari masalah pendanaan, karena struktur modal yang optimal akan memiliki dampak yang positif bagi nilai perusahaan.

2. Bagi Investor, penelitian ini diharapkan dapat bermanfaat bagi pihak investor dengan memberikan informasi tentang pengaruh struktur aktiva dan profitabilitas terhadap struktur modal. Agar sebelum melakukan investasi, investor dapat memahami informasi-informasi yang relevan yang tersedia melalui laporan keuangan yang dipublikasikan di Bursa Efek Indonesia maupun isu ekonomi terkini.

3. Bagi peneliti selanjutnya, agar menambah jumlah populasi yang hendak diteliti tidak hanya pada sektor industri barang konsumsi atau pun dapat menambah jumlah tahun pengamatan dikarenakan penelitian ini hanya dilakukan selama tahun 2014-2016. Juga dapat menambah faktor lain yang mempengaruhi struktur modal selain struktur aktiva dan profitabilitas seperti pertumbuhan penjualan, ukuran perusahaan, struktur kepemilikan, risiko bisnis, leverage operasi, dan lain sebagainya.

\section{DAFTAR PUSTAKA}

Agustini, T. 2016. Pengaruh Struktur Aktiva, Profitabilitas dan Ukuran Perusahaan Terhadap Struktur Modal. Jurnal Ilmu dan Riset Manajemen 4(8):1-16.

Akinyomi, O.J. dan A. Olagonju. 2013. Determinants of Capital Structure in Nigeria. International Journal of Innovation and Applied Studies 3(4):999-1005.

Budiarso, N.S. 2014. Struktur Modal dan Kinerja Perusahaan (Studi pada Perusahaan yang terdaftar di Bursa Efek Indonesia periode 2011 s/d 2012). Jurnal Riset Akuntansi Dan Auditing "Goodwill" 5(1):30-38.

Bursa Efek Indonesia. 2018. Laporan Keuangan \& Tahunan.www.idx.co.id.

Devi, N.M.N.C., N.L.G.E. Sulindawati, dan M.A. Wahyuni. 2017. Pengaruh Struktur Aktiva, Profitabilitas, Ukuran Perusahaan, Likuiditas, dan Kepemilikan Manajerial Terhadap Struktur Modal Perusahaan (Studi Empiris pada Perusahaan Manufaktur yang 
Terdaftar Di Bursa Efek Indonesia Periode 2013-2015). Jurnal Ilmiah Mahasiswa Akuntansi 7(1):1-12.

Febriminanto, R.D. 2012. Analisis Faktor-Faktor yang Mempengaruhi Struktur Modal Pada Perusahaan yang Terdaftar di Bursa Efek Indonesia Periode 2001-2010. Skripsi. Universitas Indonesia. Depok.

Handojo, I. 2015. Faktor - Faktor yang Mempengaruhi Struktur Modal. Jurnal Bisnis Dan Akuntansi 17(1a).

Ichwan, F.Y. 2015. Pengaruh Ukuran Perusahaan, Struktur Aktiva dan Profitabilitas Terhadap Struktur Modal. Jurnal Ilmu \& Riset Akuntansi 4(6):1-19

Kurniawan, C. 2015. Analisis Faktor - Faktor Yang Mempengaruhi Struktur Modal Perusahaan Pertambangan Di Indonesia.. Skripsi. Universitas Diponegoro. Semarang.

Nanda, D.W. dan E.D. Retnani. 2017. Pengaruh Profitabilitas, Kepemilikan Manajerial, Kepemilikan Institusional dan Resiko Bisnis Terhadap Struktur Modal. Jurnal Ilmu dan Riset Akuntansi 6(3):945-962.

Nita, N. dan A. Hairul. 2017. Analisis Faktor-faktor yang Mempengaruhi Struktur Modal Perusahaan Sektor Pertambangan. Jurnal Sosial Humaniora Dan Pendidikan 1(1):5365.

Prasetyo, A.E. 2015. Analisis Faktor-Faktor yang Mempengaruhi Struktur Modal Pada Perusahaan Manufaktur yang Terdaftar di Bursa Efek Indonesia Periode 2011-2014. Skripsi. Universitas Diponegoro. Semarang.

Putra, I.M.K.A.A., dan N.N.A. Diantini. 2015. Determinan Struktur Modal Pada Perusahaan Otomotif di Bursa Efek Indonesia. Jurnal Ekonomi dan Pariwisata 10(2): 1-11.

Restiyowati, I. 2014. Faktor-Faktor yang Mempengaruhi Struktur Modal Perusahaan Property di Bursa Efek Indonesia. Jurnal Ilmu \& Riset Manajemen 3(2):1-15.

Sansoethan, D.K., dan B. Suryono. 2016. Faktor-Faktor yang Mempengaruhi Struktur Modal Pada Perusahaan Makanan dan Minuman. Jurnal Ilmu dan Riset Akuntansi 5(1):1-20.

Sugiyono. 2016. Metode Penelitian Kuantitatif, Kualitatif, dan R\&D. Alfabeta. Bandung.

Udayani, D., dan I.G.N. Suaryana. 2013. Pengaruh Profitabilitas Dan Investment Opportunity Set Pada Struktur Modal. E-Jurnal Akuntansi Universitas Udayana 4(2): 299-314.

Vitriasari, R. dan I. Indarti. 2010. Pengaruh Stabilitas Penjualan, Struktur Aktiva, dan Tingkat Pertumbuhan Terhadap Struktur Modal. Jurnal Kajian Akuntansi dan Bisnis 1(1):1-19.

Waruwu, P. 2011. Analisis Faktor-Faktor yang Mempengaruhi Kebijakan DiViden Kas Pada Sektor Industri Barang Konsumsi yang Terdaftar di Bursa Efek Indonesia. Skripsi. Universitas Sumatera Utara. Medan.

Yushinta, P., dan E. Suryandari. 2010. Analisis Faktor-Faktor yang Mempengaruhi Struktur Modal (Studi Empiris Pada Perusahaan Manufaktur di Bursa Efek Indonesia. Jurnal Akuntansi dan Investasi 11(2):179-188.

Zahroh, F., dan A. Fitria. 2016. Pengaruh Profitabilitas, Struktur Aset,Keputusan Investasi,dan Risiko Bisnis Trhadap Struktur Modal. Jurnal Ilmu dan Riset Akuntansi $5(3): 1-15$. 